\title{
RELATIONSHIP BETWEEN ACADEMIC SELF-EFFICACY AND COGNITIVE LOAD FOR STUDENTS IN DISTANCE LEARNING
}

\author{
Inguna Griskevica ${ }^{1}$, Martins Iltners ${ }^{2}$ \\ ${ }^{1}$ Liepaja University Institute of Educational Sciences, Latvia \\ ${ }^{2}$ Rīga Stradinšs University Liepaja Department, Latvia
}

\begin{abstract}
The COVID-19 global pandemic has forced the education process worldwide to change its form to distance learning. This empirical study contributes to recently limited knowledge about the remote learning process. The study aimed to determine how academic self-efficacy is related to subjective cognitive load to predict achievement results in different forms of distance learning. The research method used was a quasiexperimental pilot study. The research questions were: (1) What is the relationship between academic selfefficacy, subjective cognitive load, and achievement results in teacher-directed distance learning? (2) What is the relationship between academic self-efficacy, subjective cognitive load, and achievement in student-directed distance learning? (3) What is the difference between teacher-directed and student self-directed distance learning settings regarding relationships between academic self-efficacy, subjective cognitive load, and achievement results? The measurement of academic self-efficacy and subjective cognitive load in the context of task assessment results were compared in different distance learning settings in two independent groups of 9th graders. The results suggest a significant relationship between subjective cognitive load and achievement results in student self-directed but non-significant between all variables in teacher-directed distance learning settings. In contrast, settings themselves demonstrated no influence on any measured factors.

Keywords: academic self-efficacy, achievement, distance learning, subjective cognitive load.
\end{abstract}

To cite this article:

Griskevica, I. \& Iltners, M. (2021). Relationship between Academic Self-Efficacy and Cognitive Load for Students in Distance Learning. Education. Innovation. Diversity, 2(2), 31-40.

DOI: https://doi.org/10.17770/eid2021.1.5426

\section{Introduction}

The pandemic caused by the COVID-19 virus has forced schools worldwide to change their form of education. According to UNESCO (United Nations Educational, Scientific and Cultural Organization), more than 1.2 billion learners in 186 countries switch to distance learning (Li \& Lalani, 2020). On November 12, 2020, the Latvia Education Law Amendment came into force defining that distance learning becomes "a part of the full-time education process" (Education Law Amendment, 2020, article 1.1.). The OECD meta-analysis study indicates that there is currently a lack of sufficient research worldwide on the impact of technology on the learning process (Gottschalk, 2019). Due to the changes that COVID-19 has forced, it is fundamental to study and understand the impact of psychological aspects in distance learning.

The study aims to determine the relationship between academic self-efficacy and subjective cognitive load in the prediction of achievement results in different forms of distance learning. The research method used was a quasi-experimental pilot study. This paper examines the relationship between academic self-efficacy, subjective cognitive load and achievement results in teacher-directed and student self-directed distance learning settings. The specific objective of this study was to investigate whether relationships in these two instructional settings differentiate. The study sought to answer the following specific research questions: (1) What is the relationship between academic self-efficacy, subjective cognitive load, and achievement results in teacher-directed distance learning? (2) What is the relationship between academic self-efficacy, subjective cognitive load, and achievement 
results in student self-directed distance learning? (3) What is the difference between teacherdirected and student self-directed distance learning settings according to relationships between academic self-efficacy, subjective cognitive load, and achievement results?

\section{Literature review}

Digital technology and the World Wide Web have changed the way people learn and acquire new information. Recently, education underwent enormous changes due to the impact of changing habits in contemporary communication driven by digital technology (Griskevica, 2018, 2020; Hooft, 2018; Howe \& Strauss, 2000). As a result of intelligent device functions development, learning materials can be accessed anywhere, anytime. However, scientists debate how such easy and fast access to a wide range of information affects people's ability to learn (Lodge \& Harrison, 2019). Although many published studies describe the relationship between cognitive abilities and education (Griskevica, 2016, 2017; Liou \& Bulut, 2020; Sternberg, 2020), it has been suggested that cognitive functions in the digital environment interact differently with learning processes than in the traditional general environment (Lodge, Kennedy, \& Lockyer, 2016; Lodge \& Horvath, 2017; Martin, Sun, \& Westine, 2020; Pigott \& Polanin, 2020; Sahni et al., 2021). It has been reported that the digital environment can increase the cognitive load and inhibit learniing. The studies show that the flow of information in cyberspace attention and memory processes impact differently than in physical space (Firth et al., 2019; Palghat, Horvath, \& Lodge, 2017). Due to the COVID-19 pandemic sudden introduction of distance education into the general learning process, it has become one of the unique challenges for all its participants. Some investigators have named it a "spontaneous experiment" because the urgent implementation of the digital learning forms was required in the ongoing education process, while research findings of the impact of the digital environment on learning are still unclear (Zavizion et al., 2020, p. 4). Factors influencing the learning process, such as teacher-directed and student self-directed distance learning settings, are considered more important than the digital environment (Kümmel, Moskaliuk, Cress, \& Kimmerle, 2020). The authors identify two orientations in the exploration of education-learning settings: individual and social in the context of which the teacher-directed and student self-directed distance-learning settings can be understood. Studies with an individual orientation explore individual learners mental representations and knowledge acquisition in digital learning environments. Studies with a social orientation, explore learners' participation in the social system and application of the learning materials in collaboration.

The last decade has seen a growing trend towards investigation the influence of academic self-efficacy on student achievements in remote learning settings (Honicke \& Broadbent, 2016; Huang, 2012; Yukuselturk \& Bulut, 2007; Joo, Lim, \& Kim, 2013). Since the term self-efficacy was reported in social learning theory, it indicates a function of selfregulation that can influence a person's behavioural and cognitive processes (Bandura, 1991, 2001). Although meta-analysis demonstrates that self-efficacy is related to academic performance in the long term (Talsma, Schüza, Schwarzerc, \& Norrisa, 2018), the results are not unambiguous, and correlation has not been determined between these entities (Bouffard \& Couture, 2003; Crippen, Biesinger, Muis, \& Orgill, 2009; Harackiewicz, Barron, Carter, Lehto, \& Elliot, 1997; Yusuf, 2011; Wahabi, 2009). Questions have been raised alongside the necessity to clarify the relationship between academic performance and academic selfefficacy in the context of different distance learning settings (Cho \& Shen, 2013; Yokoyama, 2019; Wilde \& Hsu, 2019).

Regarding cognitive processes, investigations demonstrate that higher levels of general self-efficacy correlate with the cognitive abilities that motivate oneself to attain the 
goal (Bandura, 1994, 1998; Bouffard \& Bouchard, 2005). Since the reported theory of the subjective cognitive load (Sweller, 1993, 1998), recent evidence suggests that academic selfefficacy and subjective cognitive load could exist a straight correlation within the academic environment (Vasile, Marhan, Singer, \& Stoicescu, 2011; Huang \& Mayer, 2019). Several researchers have recognized that cognitive loads are among the most influential factors with a critical role in distance learning outcomes (Curum, \& Khedo, 2020; Stiller \& Bachmaier, 2018). The Cognitive Load Theory states that instructional methods are essential to decrease extraneous cognitive load so that available cognitive resources can be entirely devoted to learning (De Jong, 2010; Chandler \& Sweller, 1992; Sweller, 2005). Cognitive overload is understood in terms of how information is processed during learning and relates to the amount of information that working memory can hold at one time. A review of performed studies on the relationship between self-efficacy and academic performance in online learning states the fact that there are extremely little published data about their influence on cognitive processes (Curum \& Khedo, 2020; Yokoyama, 2019). Although studies demonstrate that cognitive overload lowers educational performance, few published studies have examined the consequences of cognitive overload in distance learning settings (Alyushin \& Kolobashkina, 2019; Mierlo, Jarodzka, Kirschner, Kirschner, \& Kirschner, 2014; Sweller, Van Merrienboer, $\&$ Paas, 2019). These findings suggest that more exploration of human collaboration influence the learning process in e-learning is needed (Baum \& McPherson, 2019; MacKenzie, 2019; Zhampeissova et al., 2020).

\section{Methodology}

\section{Research tools}

In the study, academic self-efficacy was measured by an adapted version of the General Self-Efficacy Scale (Schwarzer \& Jerusalem, 1995; Bulina, 2009), which was modified for the academic field dimension (Cronbach's $\alpha$ is .81). The modification and adaptation of the scale for academic self-efficacy measurement were performed according to the authors' recommendation (Schwarzer, 2014). The scale is one-dimensional and consists of ten statements with four possible answers on a curved scale for each. There are ten statements in each: The respondent's task is to give his / her assessment on a 4 point Likert-type scale of the extent to which he/she agrees with each of the statements from 1 (strongly disagree) to 4 (strongly agree). Scoring sums up all ten items to generate the final composite score from 10 to 40. The designed scale is for adults and adolescents from the age of 14 . The scale is used and adapted in 32 languages (Schwarzer, 2014). It aims to determine how an individual perceives self-perceived self-efficacy in coping with daily difficulties to persevere, engage in challenging and complex situations, and successfully recover from failures to achieve their goals (Schwarzer \& Hallum, 2008).

Subjective cognitive load was measured by the Subjective Cognitive Load Measurement scale (Paas et al., 2003; 2010). On a curved scale from 1 to 9, the scale assesses how high the cognitive load was perceived during the task: 1 (very, very low mental strain) up to 9 (very, very high mental strain). The scale proves to be a reliable and valid estimator (Ayres, 2006) of overall cognitive load. The scale's design does not interfere with the learning process (Paas, Ayres, \& Pachman, 2008).

Achievement was assessed according to the English language achievement test elaborated by the teacher according to the learning curriculum of the 9th grade. The test was developed from the task samples of the state examinations on the National Center for the Education Republic of Latvia website (National Center for the Education Republic of Latvia, 2020). All together test consisted of four tasks from which two focused on reading skills and two on language understanding. The answers were rated on a Likert scale from 1 (very, very 
poor) to 10 (excellent), while in case of failure to complete the test, the students received NV (no rating).

Data collection procedure

The identical tasks and measurement procedures were performed simultaneously ( 90 minutes) in different distance learning settings. The teacher-directed distance learning settings were defined as when the teacher is present on the screen and interacts with students. The student self-directed distance learning settings were defined as ones where the teacher has prepared instructions and students work independently without teacher presence online. The procedure was performed in online settings, and the sequence of the study was the following: students completed the measurement of the modification of the General Self-Efficacy Scale for the academic dimension (Bulina, 2009; Schwarzer \& Jerusalem, 1995; Swarzer, 2014), then tasks and tests of the current English language lesson, then Subjective Cognitive Load Measurement Scale (Paas et al., 2003; 2010; Paas, Ayres \& Pachman, 2008), after the lesson the teacher evaluated achievement results.

\section{Methods of analysis}

Multiple linear regression was carried out to investigate the relationship between academic self-efficacy (scale 10-40), achievement results (scale 1-10) and cognitive load (scale 1-9). The $R$-squared $\left(\mathrm{R}^{2}\right)$ equation was used to evaluate the model fit. To report each predictor's slope of influence, the standardised coefficient Beta-coefficient $(\beta)$ was calculated with a statistical significance $p$-value. The individual predictors were examined with Student $t$ criteria with statistical significance $p$-value as predictors in the model. The scatterplot of standardised predicted residuals showed that the data met the homogeneity assumptions of variance and linearity. The residuals were approximately normally distributed. Empirical data statistically analyses were performed with SPSS (Statistical Package for the Social Science v. 26.0).

The study sample

The proximity principle made sampling. Participants came from the same educational establishment and were randomly divided into two independent groups (Group 1, $n=30$, male $50 \%$ and Group 2, $n=30$, male 50\%) aged from 15 to $16(M=15.02, S D=.05)$. The two groups were aligned by gender and average achievement results in the subject.

\section{Research results}

In order to answer the first research question, a multi-factor linear regression was used to predict achievement results based on their academic self-efficacy and subjective cognitive load in teacher-directed distance learning settings. A non-significant regression equation was found $\mathrm{F}(2,27)=1.600, p<.221$, with an $\mathrm{R}^{2}$ of .106. The individual predictors were examined further and indicated that cognitive load $(t=-.224, p=.825)$ and self-efficacy $(t=-1.695, p=$ .102) were nonsignificant predictors in the model. It means that by increasing the subjective cognitive load and academic self-efficacy by one unit, the achievement assessment decreases non-significantly. This means that academic self-efficacy and subjective cognitive load did not influence achievement results. Values of Beta-coefficients $(\beta)$ and their statistical significance $(p)$ is shown in Table 1 . 
Table 1 Indicators of the contribution of academic self-efficacy and subjective cognitive load in predicting the achievement results in the regression model for teacher-directed distance learning settings

\begin{tabular}{lcc}
\hline \multicolumn{1}{c}{ Factors } & Beta - coefficients $(\beta)$ & Significance $(p)$ \\
\hline Academic self-efficacy & .024 & .825 \\
Subjective cognitive load & -.251 & .102 \\
\hline
\end{tabular}

Significance level $p \leq .05 *, p \leq .01 * *$

In order to answer the second research question, a multiple linear regression was used to predict achievement results based on their academic self-efficacy and subjective cognitive load in student self-directed distance learning settings. Here a significant regression equation was found with subjective cognitive load $\mathrm{F}(2,27)=4.363, p<.023$, with an $\mathrm{R}^{2}$ of .244 . The individual predictors were examined further and indicated that just a cognitive load $(t=-$ $2.314, p=.029)$ was a significant predictor in the model. It can be seen from the data in Table 2 that by increasing the subjective cognitive load by one unit, the achievement results on average will decrease by .472 . This means that $24 \%$ of achievement results are influenced by subjective cognitive load.

Table 2 Indicators of the contribution of academic self-efficacy and subjective cognitive load in predicting the achievement results in the regression model for student self-directed distance learning settings

\begin{tabular}{lcc}
\hline \multicolumn{1}{c}{ Factors } & Beta-coefficients $(\beta)$ & Significance $(p)$ \\
\hline Academic self-efficacy & .028 & .353 \\
Subjective cognitive load & -.472 & $.029^{*}$ \\
\hline
\end{tabular}

Significance level $p \leq .05 *, p \leq .01 * *$

In order to answer the third research question, a multiple linear regression was used to predict achievement results based on a different type of distance learning settings. After adjustment of academic self-efficacy and subjective cognitive load by changing various distance learning settings, results did not show statistically significant differences in achievement results $p>.05$. The group factor demonstrated no statistically significant influence on achievement results, not on academic self-efficacy and subjective cognitive load. The mean values of each measured factor are displayed in Table 3.

Table 3 Mean values of the academic self-efficacy, subjective cognitive load and achievement results for students in both distance learning settings

\begin{tabular}{lccc}
\hline \multicolumn{1}{c}{ Factors } & \multicolumn{3}{c}{ Distance learning settings } \\
& Group 1 & Group 2 & Together \\
& $(n=30)$ & $(n=30)$ & $(N=60)$ \\
\hline Academic self-efficacy & 30.17 & 30.60 & 30.38 \\
Subjective cognitive load & 5.07 & 4.73 & 4.90 \\
Achievement results & 6.67 & 6.50 & 6.58 \\
\hline
\end{tabular}

Significantce level $p \leq .05 *, p \leq .01 * *$

In summary, these results suggest a significant relationship between subjective cognitive load and achievement results in student self-directed but non-significant between all 
variables in teacher-directed distance learning settings. In contrast, settings themselves demonstrated no influence on any measured factors.

\section{Discussion}

This study set out to assess the importance of a science-based approach to distance learning and clarify how motivational and cognitive aspects may interplay in this learning environment. Surprisingly, no differences were found between teacher and student selfdirected remote learning settings in mean values of academic self-efficacy, cognitive load and achievement assessment measures. Meanwhile, the study results indicated that in student selfdirected distance learning settings, subjective cognitive load impacted the achievement of assessment results. Contrary to expectations, this study did not find a significant difference between self-efficacy and achievement results in both distance learning settings.

Although cognitive loads are recognized as an essential part of distance learning (Stiller \& Bachmaier, 2018), there is still little information about its relationship to selfefficacy (Yokoyama, 2019). Contrary to expectations based on some published research (Talsma et al., 2018; Huang \& Mayer, 2019), this study did not find a significant relationship between academic self-efficacy and achievement results. These results agree with the findings of other studies, in which the relationship between academic self-efficacy and performance was questioned or even not found (Crippen et al., 2009; Cho \& Shen, 2013; Wilde \& Hsu, 2019). A possible explanation for this might lie in the difference between learning and performance goals. It is reported that this contrast exists between the goals of the effort and the evaluation of the achievement process by itself (Bouffard \& Bouchard, 2005). These results agree with the findings of other studies that demonstrate strong evidence of unclear correlations between perceived competence and achievement goals in school settings (Bouffard \& Couture, 2003; Harackiewicz, et al., 1997). These results support the idea that self-efficacy has an indirect effect on achievement motivation and self-learning strategies in academic accomplishments (Yusuf, 2011; Wahabi, 2009).

The current study does not support findings that postulate a forthright correlation between academic self-efficacy and cognitive load in the learning environment (Vasile et al., 2011). This study confirms that subjective cognitive load is mainly associated with the achievement of educational goals in the contexts of distance learning (Zhampeissova et al., 2020). The cognitive load has been recognised as a significant factor that influences achievement results in the digital environment learning processes (Al-Hunaiyyan et al., 2017). This study's observed results could be attributed to the idea that educational programs in a remote learning environment are more effective if the cognitive load is optimal (Curum \& Khedo, 2020). According to recent reports, inadequately designed educational content exceeding possible for perception elements can lead to overload and poor achievement results (Alyushin \& Kolobashkina, 2019; Sweller et al., 2019). The evidence from this study suggests that subjective cognitive load has more impact on performance in such distance learning settings where there is no direct teacher guidance. These results are consistent with those aptitude-treatment interaction studies, which suggest that in particular circumstances teacherdirected instruction reveals advantages (Chen \&Chen, 2018; MacKenzie, 2019; Martin et al., 2020). Some of these findings demonstrate that in distance learning settings, specifically students with lower reasoning ability benefit from the teacher-directed instructions (Sahni et al., 2021; Zhampeissova et al., 2020; Ziegler et al., 2020).

Summarising this study has identified the differences in two web-based tutoring versions of instructions. These findings should improve predictions of the impact of the training task's design form on the distance learning settings' learning process. Further studies, which take the studied variables into account, will need to be undertaken. However, more 
research of the larger sample on this topic needs to be conducted before the association between self-efficacy, subjective cognitive load, achievement results, and distance learning forms is more clearly understood.

\section{Conclusions}

This study set out to assess the effects of different distance learning conditions on how knowledge is acquired. The present study was designed to determine the relationships between self-efficacy, subjective cognitive load and the achievement results in remote learning settings. During this quasi-experimental pilot study the identical tests were given to two randomly divided groups in two distance-learning settings where one performed tasks under the own guidance, but the other under the guidance of a teacher.

This study has found that generally, there were no significant differences between these two groups in measurements of self-efficacy, subjective cognitive load and achievement results. In teacher-directed distance learning conditions, investigations did not find significant relationships between the studied variables. While interestingly, multiple regression analysis revealed that the cognitive load was a significant predictor in the student self-directed learning settings. The tendency showed that by increasing the subjective cognitive load in student self-directed learning settings, the assessment results would decrease.

An implication of this is the possibility that students in self-directed distance learning settings may perceive the tasks more difficult than in teacher-directed settings. These data suggest that the perception of the cognitive load has significant implications on the achievement results and in this respect, the role of teacher presence or non-presence may be critical. Surprisingly this study could not state any contribution of academic self-efficacy on subjective cognitive load and achievement. These results offer a framework for further exploration of the role of perceived self-efficacy in learning. If the subjective cognitive load is more connected with persistence, self-efficacy is more consentient with social learning skills. This study highlights the meaning of motivation over self-perception factors in the learning process.

Overall being limited to a pilot study with a small sample, the study only aimed to look at the distance learning conditions. The present study's key strength was the quasiexperimental condition imposed by Covid-19, making the design possible. Returning to the question posed at the beginning of this study, it is now possible to state that academic selfefficacy by changing various distance learning forms does not significantly impact achievement results. Still, the question raised by this study is how subjective cognitive load displays in different distance learning settings and that more exploration of human collaboration role in the e-learning process is recommended.

\section{References}

Al-Hunaiyyan, A., Bimba, A.T., Idris, N., Al-Sharhan, S. (2017). A cognitive knowledgebased framework for social and metacognitive support in mobile learning. Interdisciplinary Journal of Information, Knowledge, and Management, 12, 75-98. DOI:10.28945/3670

Alyushin, M.V., Kolobashkina, L.V. (2019). Monitoring of the current status of students as a means of increasing the effectiveness of educational process. The Education and science journal, 21(2), 176-197. DOI:10.17853/1994-5639-2019-2-176-197

Ayres, P. (2006). Using subjective measures to detect variations of intrinsic load within problems. Learning and Instruction, 16, 389-400. DOI: https://doi.org/10.1016/j.learninstruc.2006.09.001 
Baum, S., \& McPherson, M. S. (2019). The Human Factor: The Promise \& Limits of Online Education. Daedalus, 148, 235 -254. DOI: https://doi.org/10.1162/daed_a_01769

Bandura, A. (1991). Social Cognitive Theory of Self-Regulation. Organizatioal Behaviour and Human Decision Processess, 50, 248-287. DOI: https://doi.org/10.1016/07495978(91)90022-L

Bandura, A. (2001). Social Cognitive Theory. Annual Agentive Perspective. Annual Review of Psychology, 52, 1-26. DOI: https://doi.org/10.1146/annurev.psych.52.1.1

Bouffard, T., \& Bouchard, M. (2005). Influence of achievement goals and self-efficacy on students' self-regulation and performance. International Journal of Psychology, 40(6), 373-384. DOI: https://psycnet.apa.org/doi/10.1080/00207590444000302

Bouffard, T. \& Couture, N. (2003). Motivational profile and academic achievement among students enrolled in different schooling tracks. Educational Studies, 29, 19-38. DOI: $10.1080 / 03055690303270$

Buliṇa, R. (2009). Perfekcionisma, pašefektivitātes un subjektīvās labklājūbas saistība. Rīga: Latvijas Universitāte. Mağistra darbs. Retrieved from https://dspace.lu.lv/dspace

Chandler, P., \& Sweller, J. (1992). The split-attention effect as a factor in the design of instruction. British Journal of Educational Psychology, 62, 233-246. DOI: https://psycnet.apa.org/doi/10.1111/j.2044-8279.1992.tb01017.x

Chen, C.C., \& Chen, C.Y. (2018). Exploring the effect of learning styles on learning achievement in a u-Museum. Interactive Learning Environments, 26(5): 664-681. DOI: https://doi.org/10.1080/10494820.2017.1385488

Cho, M. H., \& Shen, D. (2013). Self-regulation in online learning. Distance Educ. 34, 290 301. DOI: https://doi.org/10.1080/01587919.2013.835770

Crippen, K. J., Biesinger, K. D., Muis, K. R., \& Orgill, M. (2009). The role of goal orientation and self-efficacy in learning from web-based worked examples. Journal of Interactive Learning Research, 20, 385-403. Retrieved from https://www.researchgate.net/publication/234648697

Curum, B. \& Khedo, K.K. (2020). Cognitive load management in mobile learning systems: principles and theories. Journal of Computers in Education, 1, 1-28. DOI: https://doi.org/10.1007/s40692-020-00173-6.

De Jong, T. (2010). Cognitive Load Theory, educational research, and instructional design: Some food for thought. Instructional Science, 38(2), 105-134. DOI 10.1007/s11251009-9110-0

Education Law Amendment (2020). Latvijas Vēstnesis, 224, 19.11.2020. Retrieved from https://likumi.lv/ta/en/en/id/318794.

Firth, J., Torous, J., Stubbs, B., Firth, J. A., Steiner, G. Z., Smith, L., \& Sarris, J. (2019). The "online brain": How the Internet may be changing our cognition. World Psychiatry, 18(2), 119-129. DOI: 10.1002/wps.20617

Gottschalk, F. (2019). Impacts of Technology Use on Children: Exploring Literature on the Brain, Cognition and Well-Being. OECD Education Working Papers, No. 195. DOI: https://doi.org/10.1787/8296464e-en

Griskevica, I. (2016). The Relationship among Verbal Ability and Demographic Factors in Latvia. In Laiviniece D. (Ed.), Language Acquisition: Problems and Perspectives, Part III: Research and Literacy. Cambridge Scholars Publishing, 122-134. Retrieved from www.cambridgescholars.com/product/978-1-5275-1356-3

Griskevica, I. (2017). Psychological Traits in Teacher and Pupil Mutual Communication. 3rd International Conference on Lifelong Education and Leadership for All (ICLEL). Book of Conference Proceedings, 41-51. Retrieved from www.iclel.com/iclel-17 
Griskevica, I. (2018). Education and Decline of Cognitive Abilities in Late Adulthood . 4th International Conference on Lifelong Education and Leadership for All (ICLEL). Book of Conference Proceedings: 161-164. Retrieved from www.iclel.com/iclel-18

Griskevica, I. (2020). The psychological impact of changing habits in contepmporary communication on education processes. Proceedings of the International Scientific Conference, Volume VII, May 22th -23th, 43-50. DOI: 10.17770/sie2020vol7.4813

Harackiewicz, J. M., Barron, K. E., Carter, S. M., Lehto, A. T., \& Elliot, A. J. (1997). Predictors and consequences of achievement goals in the college classroom: Maintaining interest and making the grade. Journal of Personality and Social Psychology, 73, 1284-1295. DOI: https://doi.org/10.1037/0022-3514.73.6.1284

Honicke, T., \& Broadbent, J. (2016). The influence of academic self-efficacy on academic performance: a systematic review. Educational Research Review, 17, 63-84. DOI: http://dx.doi.org/10.1016/j.edurev.2015.11.002

Hooft, G. J. (2018). New technologies and 21st-century children: Recent trends and outcomes. OECD Education Working Papers, No. 179, OECD Publishing. DOI: 10.1787/e071a505-en

Howe, N., \& Strauss, W. (2000). Millennials rising. New York: Random House.

Huang, C. (2012). Gender differences in academic self-efficacy: a meta-analysis. European Journal of Psychology of Education, 28, 1-35. ERIC: eric.ed.gov/?id=EJ996733

Huang, X. \& Mayer, R. E. (2019). Adding Self-Efficacy Features to an Online Statistics Lesson. Journal of Educational Computing Research, 57(4), 1003-1037. DOI: https://doi.org/10.1177\%2F0735633118771085

Kümmel, E., Moskaliuk, J., Cress, U., \& Kimmerle, J. (2020). Digital Learning Environments in Higher Education: A Literature Review of the Role of Individual vs. Social Settings for Measuring Learning Outcomes. Education Sciences, 10(3), 78. DOI: https://doi.org/10.3390/educsci10030078

Joo, Y. J., Lim, K. Y., \& Kim, J. (2013). Locus of control, self-efficacy, and task value as predictors of learning outcome in an online university context. Computer Education, 62, 149-158. DOI: 10.1016/j.compedu.2012.10.027

Li, C. \& Lalani, F. (2020). The COVID-19 pandemic has changed education forever. World Economic Forum Agenda Publications. Retrieved from https://www.weforum.org/agenda/2020/04/coronavirus-education-global-covid19online-digital-learning/

Liou, P. Y., \& Bulut, O. (2020). The effects of items format and cognitive domain on students'science performance in TIMSS 2011. Research in Science Education, 50, 99121. DOI: https://110.1007/s11165-017-9682-7

Lodge, J. M., \& Harrison, W. (2019). The Role of Attention in Learning in the Digital Age. Yale Journal of Biology and Medicine, 92(1), 21-28. Retrieved from https://www.researchgate.net/publication/331233869

Lodge J. M., \& Horvath J. C. (2017). Science of learning and digital learning environments. In J.C. Horvath, J.M., Lodge, J.A.C., Hattie. From the laboratory to the classroom: Translating science of learning for teachers. Abingdon, UK: Routledge. DOI: http://doi.org/10.1073/pnas.1319030111

Lodge, J. M., Kennedy, G., \& Lockyer, L. (2016). Special Issue: Brain, mind and educational technology. Australasian Journal of Educational Technology, 32(6), i-iii. DOI: https://doi.org/10.14742/ajet.3443

MacKenzie, M. L. (2019). Improving Learning Outcomes: Unlimited vs. Limited Attempts and Time for Supplemental Interactive Online Learning Activities. Journal of Curriculum and Teaching, 8(4), 36-45. ERIC: EJ1237507 
Martin, F., Sun, T., \& Westine, C.D. (2020). A systematic review of research on online teaching and learning from 2009 to 2018. Computer Education, Published online 2020 Sep 9. DOI: 10.1016/j.compedu.2020.104009

Mierlo, C. M., Jarodzka, H., Kirschner, Kirschner, F., \& Kirschner, P. A. (2014). Cognitive Load Theory in E-Learning. Encyclopedia of cyber behavior, V(1) University at Albany, USA. DOI: https://psycnet.apa.org/doi/10.4018/978-1-4666-0315-8.ch097

National Centre for Education Republic of Latvia (2020). The tasks of state examination. Retrieved from https://www.visc.gov.lv/lv/valsts-parbaudes-darbu-uzdevumi

Palghat, K., Horvath J. C., \& Lodge, J. M. (2017). The hard problem of 'educational neuroscience'. Trends in Neuroscience and Education, 6, 204-10. DOI: 10.1016/j.tine.2017.02.001

Paas, F., Tuovinen, J. I., Tabber, H., \& Van Gerven, P. V. (2003). Cognitive Load Measurement as a Means to Advance Cognitive Load Theory. Educational Psychologist, 38(1), 63-71. Retrieved from https://www.academia.edu/3476439

Paas, F., Ayres, P., \& Pachman, M. (2008). Assessment of cognitive load in multimedia learning environments: Theory, methods, and applications. In D. H. Robinson \& G. J. Schraw (Eds.), Recent innovations in educational technology that facilitate student learning, 11-35. Charlotte: Information Age. DOI: 10.4018/978-1-4666-0315-8.ch097

Paas, F., Renkl, A., \& Sweller, J. (2010). Cognitive Load Theory and Instructional Design: Recent Developments Educational Psychologist, 38(1), 1-4. DOI:10.1023/B:TRUC.0000021806.17516.d0

Sahni, S. D., Polanin, J. R., Zhang, Q., Michaelson, L. E., Caverly, S., Polese, M. L., \& Yang, J. (2021b). A What Works Clearinghouse rapid evidence review of distance learning programs. Technical appendix. Washington, DC: U.S. Department of Education, Institute of Education Sciences, National Center for Education Evaluation and Regional Assistance. ERIC: ED610886

Sternberg, R. J. (2020). Rethinking what we mean by intelligence. Sage Journals. Published online. DOI: https://doi.org/10.1177\%2F0031721720970700

Stiller, K., D. \& Bachmaier, R. (2018). Cognitive Loads in a Distance Training for Trainee Teachers. Frontiers in Education, 3. DOI: https://doi.org/10.3389/feduc.2018.00044

Schwarzer, R., \& Hallum, S. (2008). Perceived teacher self-efficacy as a predictor of job stress and burnout: Mediation analyses. Applied Psychology: An International Review. Special Issue: Health and Well-Being, 57, 152-171. DOI:10.1111/j.14640597.2008.00359.x

Schwarzer, R. \& Jerusalem, M. (1995). Generalized Self-Efficacy scale. In J. Weinman, S. Wright, \& M. Johnston, Measures in health psychology: A user's portfolio. Causal and control beliefs (pp. 35-37). Windsor, UK: NFER-NELSON. Retrieved from http://www.ralfschwarzer.de/

Schwarzer, R. (2014). Documentation of the General Self-Efficacy Scale. Retrieved from http://userpage.fu-berlin.de/ health/faq_gse.pdf .

Sweller, J. (1988). Cognitive load during problem solving: Effects on learning. Cognitive Science, 12(2), 257-285. DOI: https://doi.org/10.1016/0364-0213(88)90023-7

Sweller, J. (1993). Some cognitive processes and their consequences for the organisation and presentation of information. Australian Journal of Psychology, 45(1), 1-8. DOI: https://doi.org/10.1080/00049539308259112

Sweller, J. \& Merrienboer J. G., (2005). Cognitive Load Theory and Complex Learning:Recent Developments and Future Directions. Educational Psychology Review, 17(2), 136-150. DOI:10.1007/s10648-005-3951-0 
Sweller, J., Van Merrienboer, J. J., \& Paas, F. (2019). Cognitive architecture and instructional design: 20 years later. Educational Psychology Review, 32(2), 261-262. DOI: 10.1007/s10648-019-09465-5

Talsma, K., Schüza, B., Schwarzerc, R., \& Norrisa, K. (2018). I believe, therefore I achieve (and vice versa): a meta-analytic cross-lagged panel analysis of self-efficacy and academic performance. Learning and Individual Differences, 61, 136-150. Retrieved form https://isiarticles.com/113096.pdf

Vasile, C., Marhan, A., M., Singer, F. M., \& Stoicescu, D. (2011). Academic self-efficacy and cognitive load in students. Procedia-Social and Behavioral Sciences, 12, 478-482. DOI: https://doi.org/10.1016/j.sbspro.2011.02.059

Wahabi, M. (2017). Study on the Impact of Motivation, Self-Efficacy and Learning Strategies of Faculty of Education Undergraduates Studying ICT Courses. The 4th International Postgraduate Research Colloquium IPRC Proceedings, 59-80. Retrieved from https://so06.tci-thaijo.org/index.php/IJBS/article/view/2152

Wilde, N., \& Hsu, A. (2019). The influence of general self-efficacy on the interpretation of vicarious experience information within online learning. International Journal of Educational Technology in Higher Education, 16(26). DOI: 10.1186/s41239-019-0158$\mathrm{x}$

Yokyoma, S. (2019). Academic Self-Efficacy and Academic Performance in Online Learning: A Mini Review. Frontiers in Psychology, 9, 2794. DOI: https://doi.org/10.3389/fpsyg.2018.02794

Yukselturk, E. \& Bulut, S. (2007). Predictors for student success in an online course. Educational Technology and Society, 10, 71-83. ERIC: EJ814036

Yusuf, M. (2011). The impact of self-efficacy, achievement motivation, and selfregulated learning strategies on students' academic achievement. Procedia Social and Behavioral Sciences, 15, 2623-2626. DOI: 10.1016/j.sbspro.2011.04.158

Zavizion, V. F., Bondarenko, I. M., Avierin, D. I., Hojouj, M. I., Davlietova, N.O., Cherednychenlo, N.O., Prokhach, A..V, Mashtaler, V. E., Dmytrenko, K. O., Lohvynenko, V. V., Kyslytsyna, V. S., Sukhoversha, O. A., Khvorostenko, Y. M., Elhajj, M. H., Suzdalev, P. L., Myroniuk, T. F., Kichtenko, I. N., Hrabovskyi, Y. V., Smolina, K. V., \& Baranov, I. V. (2020). Distance learning: opportunities and challenges in quarantine. Medical Perspektives, 25(2), 4-12. DOI: https://doi.org/10.26641/2307$\underline{0404.2020 .2 .206260}$

Zhampeissova, K., Gura, A., Vanina, E., \& Egorova, Z. (2020). Academic Performance and Cognitive Load in Mobile Learning. Academic Performance and Cognitive Load in Mobile Learning, 14(21), 1-14. Retrieved from https://www.onlinejournals.org//index.php/i-jim/article/view/18439

Ziegler, E., Edelsbrunner, P. A., \& Stern, E. (2020). The benefit of combining teacherdirection with contrasted presentation of algebra principles.European Journal of Psychology of Education. Advance online publication. DOI: https://psycnet.apa.org/doi/10.1007/s10212-020-00468-3 